\title{
Investing in the human capital of the aquatic food sector - AQUA-TNET and the road ahead
}

John Bostock ${ }^{1}$

Sónia Seixas ${ }^{2 \& 3}$

${ }^{1}$ Institute of Aquaculture, University of Stirling, Stirling, FK9 4LA, UK j.c.bostock@stir.ac.uk 2Universidade Aberta, Rua Escola Politécnica, 147, 1269-001 Lisboa. Portugal. sonia.seixas@uab.pt ${ }^{3}$ MARE - Marine and Environmental Sciences Centre, Faculdade de Ciências e Tecnologia Universidade de Coimbra, 3004-517 Coimbra, Portugal

KEY WORDS

Aquaculture, education, training, learning, teaching, AQUA-TNET

\section{ABBREVIATIONS}

CEDEFOP - European Centre for the Development of Vocational Training

CFP - Common Fisheries Policy

EAS - European Aquaculture Society

EATiP - European Aquaculture Technology \& Innovation Platform

EC - European Commission 
ECTS - European Credit Transfer and Accumulation System

ECVET - European Credit System for Vocational Education \& Training

EQF - European Qualifications Framework

EU - European Union

ELLI - European Lifelong Learning Index

FAO - Food and Agriculture Organisation (of the United Nations)

FEAP - Federation of European Aquaculture Producers

FTE - Full time equivalent

HE - Higher Education

IMTA - Integrated multi-trophic aquaculture

LCA - Lifecycle Assessment

MOOC - Massive Open Online Course

NGO - Non-governmental organization

OER - Open Educational Resources

P2PU - Peer to Peer University

SARNISSA - Sustainable Aquaculture Research Networks in Sub Saharan Africa

STECF - Scientific, Technical and Economic Committee for Fisheries (EC)

STeXX - European Student Experience Exchange

VET - Vocational Education and Training 


\section{ABSTRACT}

Global aquaculture production now provides around 50\% of human seafood consumption and with expected population growth and increased per-capita seafood consumption, production is expected to rise from the current 63 million tonnes to almost 100 million tonnes by 2030 . In contrast, aquaculture production in the European Union is relatively low, having more or less stagnated since 2000, despite the EU being the largest global importer of seafood. However, a new strategy for aquaculture development is in place with every EU Member State committed to preparing a national plan. This will involve greater focus on current constraints and issues that need to be overcome through innovation and engagement with a wide range of stakeholders. This will require the input of research, knowledge exchange and human capacity building. The AQUA-TNET thematic network for lifelong learning in aquaculture, fisheries and aquatic resource management has brought together European organisations engaged in these activities since it first started in 1996. This paper aims to present some of the analyses and thinking of that network in relation to the role of education and training in strengthening the human capital of the European aquaculture sector as a contribution to overall sector development. The approach is therefore that of a review article, drawing on a diverse range of previous work to identify themes and trends to help inform future research and activities.

Further and higher education institutions play a partial but nonetheless significant role in aquaculture sector development. When considering future contributions to the sector, account needs to be taken of the changes taking place within the tertiary education sector as new technologies, global competition and government policies challenge the status quo of current organisation and practice. Though these present risks, they also offer considerable opportunities to build new collaborations, adopt new patterns of teaching and learning and 
perhaps apply new frameworks for accrediting learning and skills that could benefit the aquaculture sector. With funding from the European Commission Lifelong Learning Programme for AQUA-TNET having come to an end in 2014, future work of the network in promoting and enabling innovation will need to be reconfigured around other types of sector organisations. It may also be the right time to look towards a more global platform for aquaculture education and knowledge exchange.

\section{INTRODUCTION}

The growth of the aquaculture industry, whilst driven by emerging market opportunities, has been enabled through developing knowledge and the application of new technologies supported by private and public investments. The AQUA-TNET network, with a final remit supported by the EU Lifelong Learning Programme to promote innovation and a European dimension in the field of aquaculture, fisheries and aquatic resources management, has been active in studying and supporting the processes of knowledge creation, knowledge exchange and innovation (collectively known as "Knowledge Management"), particularly through the processes of education, training and skills development. The practice of engaging knowledgeable and skilled individuals within the aquaculture sector and investing further in developing their capacities is referred to here as "investing in human capital", encouraging the view that human knowledge and skills should be viewed alongside other capital assets of an organisation. This contrasts with the typical accountancy approach which classifies staff as either a production/operating cost (i.e. "labour") or as an overhead. As the aquaculture sector develops and matures, the needs as well as the opportunities for knowledge management are changing. Education and training practices themselves are also changing, at least partly in 
response to technological and social developments. This paper refers to some of the analyses carried out within the AQUA-TNET network which set out some of these changes, alongside the challenges and opportunities that these present for improving knowledge management and building the human capital of the aquatic food production sector as a means to enhance its performance across all relevant activities. Finally the future of the AQUA-TNET network is considered as well as its role in promoting collaboration and innovation in this area.

The primary focus of AQUA-TNET has been the tertiary education sector - i.e. postsecondary education, often divided into further education (focusing on technical skill-based training) and higher education (focusing on academic subjects and research-led curricula) ${ }^{1}$. Such education is classed as formal education as it is built around planned programmes involving assessment and accreditation of learning outcomes (e.g. the awarding of degrees, diplomas or certificates at the end of the study period). Formal education may be complemented by non-formal learning (structured/programmed but usually not assessed or accredited) and informal learning (unstructured/non programmed) which can be particularly important for life and work skills. Recognising the role and significance of each type of learning throughout an individual's life and career is a central theme of the present analysis. Combining this with an understanding of the knowledge needs within aquatic resources management and how that knowledge is generated, helps to identify directions for future initiatives to further enhance the sector's human capital.

\section{STATUS OF THE AQUACULTURE INDUSTRY}




\section{Global Aquaculture}

Global aquaculture production has doubled every decade for the past fifty years, representing the fastest-growing food sector (Samuel-Fitwi et al. 2012). Over that period, world aquaculture production increased from 5 million to 63 million tons (FAO 2014). Estimates from the World Bank (2013) predict that by 2030, aquaculture will supply $62 \%$ of seafood for human consumption and 50\% overall. They project a 2030 baseline scenario and a fast growth scenario of 93.612 and 101.220 million tons respectively.

Asia is by far the largest producer region accounting for over $88 \%$ of global production (FAO 2014). Beveridge et al. (2013) note that seafood is the most highly traded food commodity internationally and exports of seafood from developing countries (mostly Asia) exceed the total value of coffee, cocoa, tea, tobacco, meat and rice combined. However, the importance goes beyond the economic as aquaculture also contributes substantially to improved global nutrition (particularly through increased consumption of long chain polyunsaturated fatty acids) and food security. Although considerable opportunities exist for further aquaculture development, particularly in Africa, globally there are still many challenges to be faced. These range from the impacts expected as a result of climate change (Shelton 2014) through competition for feed and water resources, to environmental impact constraints and disease. All of these constitute substantial areas of current research and technological development, requiring the acquisition, management and application of scientific, social and economic knowledge.

\section{Aquaculture in Europe}

Europe represents the largest market for seafood in the world. EU seafood consumption is approximately 13.2 million tonnes; of this, $25 \%$ comes from EU fisheries, $65 \%$ from imports (AIPCE-CEP 2013) and $10 \%$ from EU aquaculture (European Commission 2013). The 
average per capita consumption by the 28 EU Member States is expected to increase from 22 $\mathrm{kg} / \mathrm{caput} /$ year in 1998 to $24 \mathrm{~kg} / \mathrm{caput} /$ year in 2030 (Failler 2007), although the consumption of fish varies substantially and is below the recommended values for human health in some countries (Seixas et al. 2012). Combined with expectations of population growth this implies an increase in demand of 1.6 million tonnes. However, despite the growing market, EU landings of wild fish and aquaculture production have been stagnant or decreasing over the last 10 years (Figure 1) (STECF 2013).

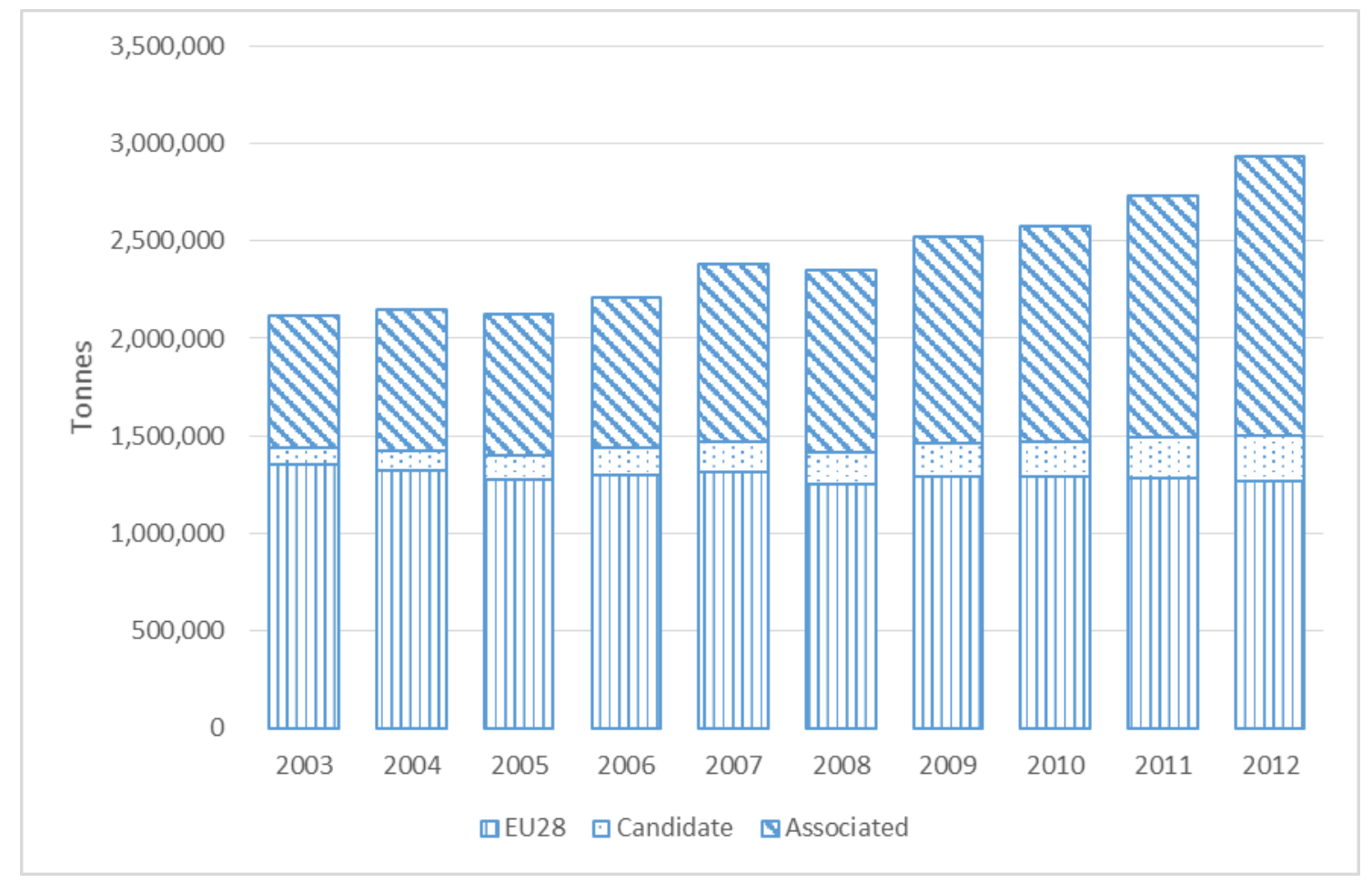

Figure. 1. European aquaculture production showing static or falling production in the 28 countries of the EU ${ }^{2}$ although growth in Norway (an Associated State ${ }^{3}$ ) and Turkey (a Candidate State ${ }^{4}$ ) has increased the overall total. Data from FAO (2014a).

Because this high dependence on seafood imports is a matter for some concern, aquaculture has been given greater attention and more positive support by the European institutions in recent years. This started in 2002 with the "Strategy for the Sustainable Development of European Aquaculture" (European Commission 2002), which was updated in 2009 
(European Commission 2009) as lack of progress was acknowledged. The strategy was further refined and published as guidelines to Member States in 2013 (European Commission 2013). Perhaps the most significant aspect of this latest communication is the requirement for Member States to prepare a multiannual national strategic plan for the promotion of sustainable aquaculture. In 2014, since these plans are either under development or have already been completed, it follows that all EU Member States have recently considered major constraints and opportunities for improving sectoral support. National plans are expected to address four priority areas:

- $\quad$ Reducing administrative burdens

- $\quad$ Improving access to space and water

- $\quad$ Increasing competitiveness

- Exploiting competitive advantages due to high quality, health and environmental standards.

Research, innovation, education and training are key aspects of the last-named area. FAO (2011) reviewing the status of global aquaculture noted that "Europe has some of the leading academic and research institutions on aquaculture in the world, contributing to the body of knowledge on sustainable development of aquaculture." The FAO report also highlighted the role of the AQUA-TNET Network: "AQUA-TNET, a pan-European education network, is considered another good model on networking that could be adopted by other regions."

The importance of research and innovation is also underlined through the formal recognition by the European Commission of the industry-led European Aquaculture Technology and Innovation Platform (EATiP) which was established in 2008. AQUA-TNET has been closely involved with this Technology Platform through its thematic working group on knowledge management. Complementing the activities of Member States and industry, the European 
Commission has established new governance priorities for themselves (European Commission 2013):

- $\quad$ Promotion and coordination of multiannual national strategic plans

- $\quad$ Complementarity with European Maritime and Fisheries Fund

- $\quad$ Exchange of best practices

- $\quad$ Creation of an Aquaculture Advisory Council

This means there is greater impetus and institutional focus for aquaculture development in the European Union than at any time in the past. Now is therefore the most appropriate time for European tertiary education institutions to engage and help ensure that future knowledge management and human resource needs are well addressed.

\section{Specific challenges}

Substantial progress has been made on aquaculture production technologies. The EU aquaculture sector is now turning over $€ 4$ billion per year (STECF 2013) which is doubled ${ }^{5}$ when Norway is also taken into account. Primary issues for the industry are often focused on access to sites (encompassing issues around the use of natural resources and ecosystem services) and constraints to productivity including disease, feeds, genetics and water quality. Substantial research is ongoing in each of these areas involving both government and commercial funding. Other issues include labour productivity and aquaculture product marketing. The latter includes consideration of consumer perceptions of aquaculture produce which may be influenced by both critics and advocates of the industry. Ensuring that valid concerns are properly addressed through measures to ensure the quality and provenance of aquaculture products and the environmental sustainability of production processes is now essential. A good example of this is the development of voluntary standards and third party certification schemes. These are frequently based on ethical values, including for instance: environmental protection, animal welfare, fair trade and quality management. Implementation 
by companies can raise standards and improve performance. The standard-setting process promotes multi-stakeholder engagement and encourages innovation; although the management of this can itself raise difficult ethical issues (Bush et al. 2013).

Technical innovations aimed to ensure environmental sustainability range from the design and engineering of open ocean aquaculture systems ${ }^{6}$ to environmentally closed systems with full water treatment and reuse (Martins et al. 2010). Another significant trend is increased interest in production systems based on optimising use of ecological processes, natural resource use and ecosystem services (FAO 2010). For instance various types of integrated aquaculture where nutrients released from one production process can contribute as inputs to another, e.g. Integrated Multitrophic Aquaculture (IMTA) (e.g. Troell et al. 2009; Irisarri et al. 2013), aquaponics (Love et al. 2015); or the processing of low-value organic wastes to higher value aquafeeds through insects (Čičkováa et al. 2015; Barroso et al. 2014) or vermiculture and vermicompost (Guerrero \& Guerrero 2014). Whilst there are technical constraints, the major challenge is economic sustainability. The solution to this may be to take a broader approach through consideration of the whole value chain and integration with other industries and activities; for instance the EC policy for a Circular Economy (European Commission 2014), or the use of Lifecycle Assessment (LCA) to identify areas for optimisation (Cao et al. 2013). Organisations active in aquaculture education and training will be engaged in many of the above challenges and areas of innovation through research or specific training activities.

\section{Human capital in the aquaculture sector}

\section{Global}

Valderrama et. al. (2010) estimated total global aquaculture employment at around 23.4 million full-time equivalents, including 16.7 million direct and 6.8 million indirect jobs, the 
majority of which are in Asia. Looking more closely at a selection of aquaculture companies around the world, Hishamunda et. al. (2014) found aquaculture employees of grow-out operations are predominantly male, aged from 20 to 40 but with wide variance in the proportion with tertiary education qualifications. They reported just $1.8 \%$ of employees having a university education in the Norwegian aquaculture industry, compared with $34.5 \%$ of employees in Scotland. Vietnam had the highest proportion of university-educated employees (40\%) whilst countries in the intermediate range were the Philippines (14\%), Thailand (12\%) and India (3\%). Vietnam was also notable in having few staff with intermediate qualifications, as $47 \%$ had not even had a secondary education. However, it seems likely that these figures are taken from limited surveys where patterns of employment in specific companies have influenced the result. The higher proportion of graduates in Vietnam for instance is attributed to more expatriates working in a foreign-owned company. Nevertheless, when multiplied by the number of people employed in the sector, the demand for aquaculture-related education is substantial. A related issue is gender balance. In Thailand and Vietnam women form the majority of the employed graduates whilst in Scotland, women account for a much lower percentage of the workforce (and hence of graduates employed), although the proportion of women educated at university level comprises 50\% (significantly higher than males).

\section{Europe}

Within the Member States of the European Union, full-Time Equivalent (FTE) employment in the marine aquaculture sector is estimated to be 2,696 (4,907 people) with a further 2,470 FTE (3,963 people) in the freshwater sector (total 5,166 FTE and 8,870 people) (STECF 2013). The proportions educated to different levels were not examined in this study, but the "Well educated workforce" is noted as a competitive advantage for Europe. More relevant to future innovative educational practices perhaps, are the levels of engagement with lifelong 
learning. This, an important part of EU economic development since the Lisbon Agenda ${ }^{7}$ in 2000, was given renewed impetus in the EU Education and Training 2020 Strategy (European Commission 2009a). The latter includes a target that at least $15 \%$ of $25-64$ year-olds should participate in lifelong learning. Across Europe, progress is being made, with measured participation rates rising from $9.1 \%$ in 2010 to $10.4 \%$ in $2013^{8}$. Variation between countries however is likely to be very high. The Bertelsmann Stiftung European Lifelong Learning Index $^{9}$ (ELLI) scores individual countries on 36 different indicators in four main sub-groups which are combined into a single score. Leading the table with the highest scores are Denmark, Sweden, Netherlands and Finland, whilst those towards the bottom include Hungary, Greece, Bulgaria and Romania. Few data are available on lifelong learning engagement rates within the European aquaculture sector although data collected on lifelong learning provision by the AQUA-TNET project (Eleftheriou \& Seixas 2014) show that a higher percentage (54\%) of AQUA-TNET member institutions have a lifelong learning strategy than the general EU average (39\%). Furthermore, 63\% of AQUA-TNET member institutions have study programmes adapted for flexibility in order to enable broader participation, although a smaller percentage $(31 \%)$ have mechanisms enabling an individual to obtain credits towards one of their programmes through evidence of work experience only.

The overall picture is of a significant proportion of the European aquaculture workforce with previous and/or likely future interest in lifelong learning activities. These may range from informal, work and experience-based activities through a wide range of technical and specialist training to accredited continuing professional development at a higher education institution. The ways in which this may develop in the future are considered firstly in the broadest context and then with specific reference to the aquaculture sector. 


\section{Trends and drivers in tertiary education and training}

The future of aquaculture education and training, whilst influenced by the specific needs of the sector will be heavily shaped by broader developments in educational policy, practice and organisation. These are considered further in this section.

\section{Globalisation and commercialisation}

Perhaps the most notable trend in tertiary education over the past 20 years has been the increasing access that has been offered to degree level higher education, accompanied by a widening range of courses. Global enrolment in tertiary education more than doubled from a mean of $14 \%$ in 1990 to $30 \%$ in 2010 , whilst for higher income countries it rose from $43 \%$ to 73\% (World Economic Forum 2014). Within Europe the Bologna Process and policies for the creation of the European Higher Education Area have had a major influence and played an important role in promoting student mobility and transparency in higher education. However, since 2008 the global economic crisis has impacted substantially on the sector, albeit in different ways depending on individual national policies (Sursock \& Smidt 2010). At the EU level, greater focus was placed on the role of tertiary education as a driver for economic growth with the Commission Communications "Supporting growth and jobs - an agenda for the modernisation of Europe's Higher Education Systems" (European Commission 2011) and "Rethinking Education: Investing in skills for better socio-economic outcomes" (European Commission 2012). Looking to the future, the expectation is for even greater change in the structure and role of tertiary education. At the centre of this is the development of the Internet and the gradual but ultimately profound influence this may have on the organisation, support and recognition of learning in a more globally connected world. Specifically it is clear that an increasing amount of formal and informal learning will be mediated through Internet 
services). While much attention has been given to the potential of the Internet to cater for learners who are not in the same place or even time-zone, the Internet is also gradually transforming on-campus learning as programmes increasingly adopt blended learning approaches (Bonk \& Graham 2012). Technically significant developments include increasing bandwidth which will allow more reliable video streaming and communications, and the widening range of Internet-connected mobile devices that are available.

Early use of the Internet in formal education tended to use existing models of distance learning supplemented with bulletin board style discussion forums. From a pedagogical viewpoint, relatively little changed with the launch of Massive Open Online Courses ${ }^{10}$ (MOOCs), which first came to widespread public attention in 2012. There are a number of models, and various means of classification, the most basic shown in Table 1.

Table 1: Simple MOOC typology and examples

\begin{tabular}{|l|l|l|}
\hline Type & Characteristics & Examples \\
\hline cMOOC & Based on constructionist pedagogy and network-based & \#ETMOOC \\
learning. Content is generated by both teachers and & learners. Decentralised and using any suitable Web 2.0 \\
tools. & \\
\hline sMOOC & $\begin{array}{l}\text { Standard MOOCs (less commonly used classification), } \\
\text { mixes elements of c and x MOOCs; teacher-led task } \\
\text { based learning with group discussions and activities }\end{array}$ & Coursera \\
\hline xMOOC & $\begin{array}{l}\text { Extended, Scalable MOOCs that are highly } \\
\text { centralised, using instruction-led learning with greater } \\
\text { focus on delivery of content and tests to confirm }\end{array}$ & iversity, \\
& $\begin{array}{l}\text { learning } \\
\text { OpenUpEd }\end{array}$ & \\
\hline
\end{tabular}

Source: Synthesis of information e.g. from Jacoby (2014) \& Taneja \& Goel (2014) 
cMOOCs offer the most radical pedagogical model, but an evaluation of six MOOCs delivered by the University of Edinburgh during 2013 including one cMOOC found this to have the lowest student satisfaction score (64\% of responses to a post-course questionnaire, with only 50\% achieving their learning goals) compared with an average across all six courses of $98 \%$ (Anderson 2014). All the MOOCs had a relatively low completion rate (12\% of enrolled learners or $26 \%$ of those who accessed at least the first week materials), but this may be linked with the lack of financial investment on the part of participants, or the award of academic credit by the University. The University also recognised that "the minimal direct learner support offered in MOOCs, as well as the large numbers of learners presented pedagogical challenges, and these in turn posed a risk to reputation" (Anderson 2014). So far the main interest in MOOCs has come from lifelong learners (only 15\% of MOOC participants in the above study were students). However, the University may encourage their students to take MOOCs produced by other institutions as part of their degree courses at Edinburgh, and materials created for Edinburgh's own MOOCs will be repurposed for use in their on-campus courses (Anderson 2014). Increased use of third party teaching materials and even course modules might be seen as a small move towards the unbundling of higher education envisaged by Wang (1975).

In early 2013 the UK Institute for Public Policy Research published a report “An Avalanche is Coming: Higher education and the revolution ahead" (Barber et al. 2013). This argued that the patterns of globalisation and technology adoption that have radically altered many other sectors are increasingly affecting higher education. Within Europe (as in most other parts of the world), there is widespread recognition of tertiary education as a public good and therefore a justifiable area for public funding and state provision. However, there is also a recognition that tertiary education brings particular benefits to those who receive it, and that it is therefore fair to expect those individuals (especially at university level) to contribute to 
the cost of that education in some direct way (Docampo 2007). The balance between public good and private benefit is much debated in terms of higher education policy and there is some divergence between European countries in terms of resultant policy decisions. Whilst support for the public good of higher education remains strong (e.g. European Higher Education Area Ministerial Conference 2012), economic conditions do not allow sufficient public funding of higher education to fulfil aspirations on both quality and increased access. Combining this with the view of many, that students should be responsible for some of the cost of their education, the trend in many countries has been towards the introduction and/or increase in student fees. Where this is done in a variable way (i.e. with different institutions and courses charging different fees) Barber et al. (2013) suggested that higher education is being transformed into a more market-based sector. This will be characterised by competition on value for money and flexibility in meeting the specific needs of different types of students, as well as on academic quality, the learning environment and institutional reputation.

One indication of the strengthening perception of higher education as a marketplace with universities as service providers and students as customers, is the greater weight placed by both students and public policy organisations on international university rankings such as the Shanghai Rankings ${ }^{11}$, Times Higher Education World University Rankings ${ }^{12}$, or the QS World University Rankings ${ }^{13}$ (Deem et al. 2008). With around 22,123 higher education institutions in the world ${ }^{14}$, encouraging students to focus their ambitions on just the top 500, or even the top 100 could put serious pressure on lower-ranking institutions, particularly as they are also likely to receive less research and other funding as national governments seek to maintain or improve the position of their top institutions in the international rankings. Leading institutions are often able to charge higher student fees, and in the UK for instance, are being freed from previous restrictions on student numbers ${ }^{15}$ (Vidovich \& Currie 2014). 
At a local or regional level, trends towards consolidation can be seen as institutions merge or form strategic alliances. Internationally there is a growing number of franchise schemes where lower-ranking universities are able to offer some degrees awarded by a higher-ranking overseas university. There is also an increasing number of leading universities investing in overseas campuses as a mechanism for growth and competitiveness (Altbach 2013).

Universities are becoming more and more aware of the importance of name recognition and public image in the competitive world of managing and marketing what is effectively their brand name. In theory there might be little difference between a high-ranking and a lowranking university degree in a specific subject with respect to level and learning outcomes. However, the name of the awarding institution can have a great impact on the way the qualification is perceived within professional and social contexts and hence can exercise a significant influence on career prospects. Brand recognition is clearly an important element in any successful marketing strategy; concomitantly, it would appear unlikely that thousands of roughly similar brands could remain successful in a globalising world. However, successful brand names are generally developed around a specific set of values and gain strength through a reputation for delivering on those values. If top universities are competing on quality and a reputation for being an elite (both in terms of academic staff and students), then substantial growth may well undermine that reputation (Anderson 2014). On the other hand, organisations that are able to compete in a broader market on value (quality to cost ratio) and meet other student needs such as flexible teaching patterns, accreditation of prior learning, a better focus on generic skill development or access to career opportunities e.g. through internship programmes, could certainly flourish.

Whilst there is evidence and indicators that trends towards commercialisation and consolidation might accelerate, it must be borne in mind that the higher education sector is more complex than other product or service industries where such trends are widely 
observed. The public good aspect is a strong counterweight, as are many of the traditions of academic freedom and integrity. These can provide a strong critique of the impact of commercialisation on the intrinsic value of research and learning, and in particular the tendency for accompanying managerialism to inhibit true innovation and discovery, and level quality down to metrics that can be easily monitored (e.g. Nixon 2004).

A second factor, also linked with the public good aspect, is the role of higher education institutions in supporting local and regional development. For instance these institutions are seen as essential partners in the EU Cohesion Policy on Smart Specialisation (European Commission 2014a). This may prove a counterbalance to increasing internationalisation.

Thirdly, higher education organisations are themselves assemblages of faculties, schools, departments, institutes or other organisational sub-units with potentially different strategic objectives and perhaps with reputations in their own right. Patterns of partnerships and strategic alliances adopted by one department are likely to be completely different to those of another. The trend in public funding is increasingly to support research-themed centres of excellence which are created through collaborative alliances of more subject-specific subunits of higher education organisations. These may not have a separate legal identity or indeed finance and strategy beyond relatively short-term funding horizons. They represent a consolidation of organisation and resources, but not a consolidation through ownership, and again may provide a counterweight to a simple trend for organic and acquisitive growth.

For prospective students of fisheries and aquaculture, the relationship between the legal entity of the university and the organisational entity of the department is significant. There would probably be little correlation between the global academic league tables and the institution which might offer the best or most suitable place of study for a particular individual. However, if the league tables become more comprehensive and fine-grained with respect to 
academic divisions (not just whole institutions or faculties) this may change, forcing less specialised departments to drop certain subjects.

The main role of the European Qualifications Framework (EQF) is to make qualifications more readable and understandable across different systems and countries; its eight reference levels enable it to act as a translation device capable of covering all qualifications (HE, VET, formal and informal learning) at all levels. The slow but ongoing development of the ECVET (European Credit system for vocational education and training) system similar to the HE ECTS system, was designed "to facilitate the transfer, recognition and accumulation of assessed learning outcomes of individuals aiming to achieve a qualification" (CEDEFOP 2014). Thus many institutions will now take informal learning acquired through on the job experience, learning from peers, and short professional courses into account in the form of accreditation of prior learning; which is usually used as a means to grant access to course participation where the applicant might not have the normal prerequisite academic qualifications. In some cases it might also reduce the required length of study, for instance via a fast-track option into the second year of a programme. An EU project, VMPass ${ }^{16}$, is currently developing improved tools for this procedure though direct access to assessment and accreditation is not so far generally available.

\section{Open Educational Resources}

Another important consideration for the future is the open educational resources movement. This is linked with the move towards open-access academic publishing and is strongly supported by the European Commission (European Commission 2013). Open Educational Resources (OER) that are licenced for free distribution, re-use and modification have the potential to improve standards and increase efficiency as they would help to eliminate much duplication of effort especially at undergraduate level. However, adoption of OER faces barriers with respect to organisational culture and current models of institutional 
competitiveness at both national and international levels. It also poses significant challenges to commercial providers of educational materials. Nevertheless, further progress on OER could reduce the competitive advantage of growth through consolidation and help smaller institutions to focus on distinctive strengths whilst utilising materials from a much wider international pool. These benefits might accrue if there is a substantial growth in the creation and use of open educational resources as promoted by the EC policy on Opening up Education (European Commission 2013a). By their nature, these are free to use and modify, so the quality should rise as materials are used and improved throughout the community. Increasingly such materials are likely to include video, case studies (e.g. AQUACASE ${ }^{17}$ as developed by the AQUA-TNET network) and interactive exercises. Individual teachers will be able to spend less time preparing materials and delivering lectures on topics outside of their immediate expertise, and more time inspiring and supporting student learning through the example of their own work.

\section{Institutional responses to flexible and person learning pathways}

Taking the above trends and drivers together, the expectation is that learners will increasingly be able to determine their own flexible learning pathways involving a variety of tertiary education providers and utilising a more open and transparent assessment and accreditation system. The most important driver for this is an expectation that higher education will play a more important role in the future in lifelong learning. For this to happen, the higher education sector has to provide a greater range of learning support provision that properly meets the needs of both private and public sector enterprise and administration. This will involve flexible modes of delivery (e.g. online or short periods of face-to-face activity), greater opportunity for inter-disciplinary study, and support for work-based learning. This interaction can also be two-way as higher education establishments should be able to draw 
more effectively on the knowledge and expertise of industry and policy organisations to enhance applied research and the relevance of all taught courses (Higher Education Strategy Group 2011; TLRP 2008).

Some of the implications for higher education are summarised in a report by Ernst \& Young (2012). Although this focuses on Australia, there are many similarities with the European situation. The report states: "Our primary hypothesis is that the dominant university model in Australia - a broad-based teaching and research institution, supported by a large asset base and a large, predominantly in-house back office - will prove unviable in all but a few cases over the next 10-15 years". They identify three lines of future evolution: "Streamlined status quo" where the underlying model is relatively unchanged, but with increasing transformation of the way services are delivered and the institution is administered; "Niche dominators" where institutions specialise on a particular market segment where they can gain competitive advantage; and "Transformers" that will change the fundamental models of further education through greater involvement of the private sector, industry and media. This vision is clearly based on an underlying market-based analysis that envisages commercial business model responses. There will be considerable support for this, particularly with respect to debates about how much public funding should be used for tertiary education and how much access that provides. The more ambitious supporters of open educational resources however, might see this as an alternative route to increasing participation and efficiency whilst maintaining academic independence and freedom. Online initiatives such as the Peer to Peer University ${ }^{18}$ (P2PU) or Wikiversity ${ }^{19}$ reflect a growing interest, particularly for adult learners, in collaborative learning opportunities that are accessible, flexible and low cost whilst achieving similar intellectual standards as traditional university courses. It remains to be seen to what extent such initiatives will supplement or substitute the provision of the "bricks and mortar" colleges. 
For the foreseeable future however, it seems certain that the door is open to all types of innovation and that there will be substantial changes in tertiary education patterns and participants in the coming years.

\section{The future of aquaculture education}

\section{Taught course programmes}

The AQUA-TNET education portal ${ }^{20}$ lists almost 150 European master's programmes in aquaculture, fisheries and aquatic resources management. Around one third of these relate directly to aquaculture education. Virtually all these programmes started in the last 20-30 years, many within the last 10 years. This growth is undoubtedly linked with the development of aquaculture worldwide over the same period. With aquaculture production expected to double again by 2050 (Waite et al. 2014), tertiary education in this area will need to continue to expand and develop to meet the needs of the sector. The question is whether this should be more of the same, or if there are opportunities for innovative approaches that better meet the needs of individual learners, sector enterprises and the wider society.

A first consideration is the way in which research and practice are expanding aquaculture curricula. The variety of aquaculture practices is increasing and the technologies employed are broadening. Companies within the sector are growing in size and sophistication, requiring a greater range of specialist skills from the biological and environmental through engineering and information technology to marketing, logistics, finance and human resources management. Indeed it can be argued that the challenges faced in the future can only be overcome through a systemic and interdisciplinary approach, requiring corresponding skills and breadth of knowledge (Domik \& Fischer 2011). Similarly, the growth in the aquaculture sector requires greater expertise and specialisation in government agencies and local authorities. Implications span spatial planning, economic development, food security, health 
and safety at work and for consumers, environmental protection, energy and recycling, employment, social justice and livelihoods. Given the finite nature of formal courses, providers need to balance breadth and depth in the curriculum. The processes for doing this within the further education sector (vocational qualifications) are reasonably transparent and usually involve consultation with industry. Many such courses are now based on clearlydefined national occupational standards (e.g. for the UK see LANTRA 2010). Curriculum choices in higher education are often more influenced by the interests and expertise of the research staff at the institution offering the course, although the introduction of learning outcomes as a methodology for course design (e.g. the TUNING Process - Lokhoff et al. 2010) have gone a long way to making this more transparent. Where topics are clearly identified as important to the course, but expertise is not available within the offering institution there may be collaborations with other institutions or less formal arrangements through "invited lecturers". However, only in a few cases would this constitute more than a small percentage of the course as a whole.

\section{Flexible and lifelong learning}

Particularly if formal education providers are to play a greater role in lifelong learning, it is clear that a "one size fits all" approach to programme design fails to meet the needs of a diversifying prospective student population and the needs of private and public stakeholder organisations seeking skilled and knowledgeable staff for a wide range of aquaculturerelated roles. This should also include better integration between practically-oriented training and research-based learning so that learners can move between these as their needs and abilities change. As no single institution can claim cutting edge expertise across all areas relevant to aquaculture, opening up the system for greater cooperation and student mobility (whether actual or virtual) could bring substantial benefits for all stakeholders. 
The well-entrenched practice of teaching in cohorts is partly driven by considerations of efficiency and scale economies, which indeed is being carried over into the design and practice of MOOCs. Whilst this might appear to run counter to the objectives of providing a personalised learning pathway for students, there are substantive reasons why cohorts also work for students. Most importantly they usually provide a peer support network where social and intellectual interactions combine to stimulate, encourage and motivate (Drago-Severson et al. 2001). The mechanisms for this are complex and need to be considered in the wider context of institutional learning environments, but failure to reproduce this combination of discipline, encouragement and support in e-learning contexts for instance, has seriously limited the value of this approach (Franceschi et. al. 2009). E-Learning is usually asynchronous and independent of location, so without substantial effort, learners can feel isolated and communications are often somewhat formalised and limited to course topics. This is further compounded if learners are also following a course at different rates. Solutions to this are being sought through video conferencing, virtual worlds and the structuring of the learning process itself. However, the appeal of the physical campus will remain, especially for young adults seeking to broaden their horizons, and blended learning (combining face-toface with online) will most likely predominate with due attention to sequencing issues.

Evidence for this model can be found in the way that Universities and colleges are increasingly competing on the basis of their appeal as a living and learning environment for students. Within the UK for instance, universities are ranked on the basis of student experience surveys by Times Higher Education ${ }^{21}$ whilst the European Student Experience Exchange (STeXX) website ${ }^{22}$ provides a more dynamic and Europe-wide guide for students considering where to study. One vision anticipates students being able to make their choice from a wider range of learning environments and learning support provision and then build their own study programme from accredited units offered by other institutions and 
organisations via the Internet. For aquaculture students, such a future development might allow them to be based at one institution with research facilities catering for the species or aspects of aquaculture that most interest them, and to combine courses from that institution with those from other institutions that perhaps have greater specialisation in aspects such as disease, genetics, nutrition, engineering or business management. In this way, students could have greater flexibility to follow a learning path that suits them; and institutions could compete on aspects such as physical location, generic support for learning and individual course (unit) offerings.

\section{Social and work-based learning}

A more radical vision of the future of aquaculture education emerges if learning is seen in a broader lifelong and social context in which universities play an important but not dominant role. Universities are naturally at the centre of higher education as being research-driven, they are able to teach from the forefront of current knowledge on their specialist research topics. However, now that we are in a knowledge-driven economy ${ }^{23}$ and many organisations aspire to be learning organisations (Senge 2006), both the generation of knowledge and the need to share and apply it is more widespread and progressing at a faster rate than in the past. There is widespread recognition that individuals need to be lifelong learners and that more efficient and continuous knowledge exchange is needed between research, education and industry (e.g. The Innovation Triangle - Soriano \& Mulatero (2010)). This implies a change in the traditional concept of a senior teacher transferring knowledge to a junior learner and opens up the role of "teacher" to anyone who shares their knowledge or mentors other learners whilst they themselves are participating in the learning process. In the lifelong learning perspective, it is the learning itself, the development of capacity, the exchange of knowledge and the progress this brings to society and for economic growth that are key. The attainment of 
qualifications is perhaps a useful marker, but can equally be a distraction from the real value of learning for personal, social, technological and economic development.

Translating this to the aquaculture context, it is clear that professionals within the industry can combine explicit and tacit knowledge into real expertise in the management of their business and are often fully engaged in innovation. Aquaculture education could be significantly enhanced by greater input from industry. Equally, valuable understanding and insights that exist with academic researchers may not be well passed on to industry practitioners, particularly in the more traditional and SME sectors. The EU is addressing this perspective through support for strategic, knowledge and skill alliances in the Erasmus+ funding scheme ${ }^{24}$ from 2014-2020. This is intended to encourage concrete knowledge exchange links between tertiary education and industry at both regional and EU levels. For this to be effective there will need to be a cultural change in both academic organisations and industry. For academia it will require greater recognition of the expertise that exists in industry and a willingness to engage as learners and not just teachers in collaborative knowledge generation. For industry it will require a greater openness and willingness to share knowledge, which will run counter to the practice of most companies that regard knowledge as proprietary and having to be protected as a source of competitive advantage. They will need to move over to a strategic vision that sees sharing knowledge as a means of accelerating their own learning and as a driver for improving its implementation into innovation.

As such a cultural change may be difficult for established organisations, greater innovation might come from start-ups and individuals responding to wider social change. One notable trend has been the rise of social networking, and in particular professional networking through the Internet. The best-known service is probably LinkedIn ${ }^{25}$ which has thousands of special interest discussion groups and promotes networking across the usual barriers of 
organisations, ages and location. More focused on research is ResearchGate ${ }^{26}$ or Academia.edu ${ }^{27}$ which combine professional networking with the sharing of research results and more academic discourse. Also of note for aquaculture is SARNISSA (Sustainable Aquaculture Research Networks in Sub Saharan Africa ${ }^{28}$ ) which has greatly facilitated knowledge exchange and promoted research and learning in Sub-Saharan Africa. Further development of such networks and the skills to use them for professional learning and collaboration could overtake the occasionally pedestrian efforts of established institutions and corporations. As more detailed and comprehensive data are made available online, specialist software tools are emerging to help individuals or organisations to find relevant network connections that are non-intuitive and not based on existing patterns of contacts ${ }^{29}$. The use of such networking as part of a personal learning strategy is well documented through the concepts of Personal Learning Environments and Professional Learning Networks (Ivanova 2009) and underpinning theories of connectivism (e.g. Downes 2012) and communities of practice (Wenger 2012). Combining these highly personalised approaches with emerging indicators of esteem and achievement (e.g. badges - such as those used in the Open Course on Technology Enhanced Learning ${ }^{30}$ organised by the Association for Learning Technology ${ }^{31}$ (Anderson 2014) or Mozilla OpenBadges ${ }^{32}$ which may be endorsed by industry) could lead to a change in perceptions of the value of self-motivated and collaborative learning endeavours (e.g. Briggs 2013).

\section{The future of AQUA-TNET}

As this paper has discussed, the aquaculture industry will both grow over the next 25 years and innovate to address current constraints and meet emerging priorities. Tertiary education will likewise be obliged to adapt to a greater use of technology, increased internationalisation, wider, more flexible and lifelong access, and closer collaborations 
between research and practice. Over the past 18 years the AQUA-TNET network has provided a forum for analysis and debate, but more importantly it has provided a platform for a wide range of collaborative actions that have benefitted students of aquaculture, fisheries and aquatic resources management in Europe and through them the industry as a whole. As the EC Erasmus Thematic Network funding comes to an end in 2014, the current format of the network has to change and new measures must be put in place to sustain existing or new activities. The means for this are yet to be found, but the following priorities and potential avenues for development have been identified.

Firstly it is essential for the aquaculture sector to remain engaged in EU policy development for both education and innovation. The primary channel for this is expected to be the European Aquaculture Technology and Innovation Platform ${ }^{33}$ (EATiP) and particularly its initiatives within the Thematic Area of Knowledge Management. EATiP is formally recognised by the EU as representing the European Aquaculture Sector with respect to setting a strategic research and innovation agenda and contributing to the definition of EU and national level research priorities. It is an industry-led stakeholder forum that is expected to mobilize industry and other stakeholders within the EU to work in partnership and deliver on agreed priorities. It is also expected to share information and enable knowledge transfer to a wide range of stakeholders across the $\mathrm{EU}^{34}$. EATiP is therefore an ideal forum for working out engagement between industry, research institutes, universities, colleges and policy organisations and integrating related initiatives.

Secondly, some of the broader networking functions of AQUA-TNET can be maintained under the umbrella of the European Aquaculture Society ${ }^{35}$ (EAS); in particular the opportunity to hold meetings or workshops in conjunction with the annual Aquaculture Europe event and to help develop EAS activities and profile in the area of teaching and learning. Themes to continue in this way may include new pedagogies and support for the 
development of digital teaching and learning skills; collaboration on courses and materials including the agenda for open learning; promotion and collaboration on multidisciplinary and generic skill development; the promotion and support of lifelong learning; and consideration of quality and new assessment methods.

Thirdly, current AQUA-TNET members will seek out new opportunities for funded projects, through Erasmus+ or other EU or national funding programmes. These may well have a relatively narrow focus, and limited participants, but through concrete actions will help to drive further innovation. As a founding member of AQUA-TNET with specific capabilities in project management and knowledge exchange, Aqua TT ${ }^{36}$ (not-for-profit SME based in Ireland) could be a hub for linking these initiatives and maintaining key AQUA-TNET assets and services (in as much as these can be funded through project initiatives). This includes the Education Gate portal for information on organisations, courses and mobility opportunities.

Fourthly, AQUA-TNET members should perceive it to be in their own institutional interests to continue to pursue bilateral and wider opportunities for joint courses and programmes, or to design their own courses and accreditation systems to be more open to students who wish to pursue individual learning pathways. Combining this with greater engagement with aquaculture businesses and other institutional stakeholders would improve access for all interested learners to the highest quality and the most relevant learning opportunities. As an intermediate or partial step, greater use can be made of open educational resources (OER) through appropriate creative commons licensing and use of common repositories by all AQUA-TNET members ${ }^{37}$.

Lastly, this may be the point in its history where AQUA-TNET makes the transition from a Europe/EU- centred organisation, to one that seeks wider international collaborations and a more global outlook in its contribution to teaching, learning and knowledge management in 
aquaculture and related aquatic resources management. Most of the key issues discussed in this paper are global in scope and increasing internationalisation will in any case affect the European tertiary education sector. Furthermore, with the majority of aquaculture practice and most of the growth being outside Europe, a global vision and strategy is needed to take best advantage of the opportunities that may arise. Partnerships are therefore being explored with associations and other organisations around the world that may share similar aims and objectives to AQUA-TNET.

\section{Acknowledgements}

The authors would like to thank Margaret Eleftheriou for assistance with editing and the reviewers for their helpful comments.

\section{References}

AIPCE-CEP (2013) Finfish Study 2013. EU Fish Processors and Traders Association, Brussels. Available via http://aipcecep.drupalgardens.com/sites/g/files/g402611/f/201312/FinFish\%20Study\%202013 .pdf Cited 8 Aug 2014

Altbach PG (2013) Is there a future for branch campuses? Chapter 22 IN: The international imperative in higher education, global perspectives on higher education, pp 101-106, Sense Publishers. http://dx.doi.org/10.1007/978-84-6209-338-6_22

Anderson, M. S. (2014) Distance Learning: Contemporary Approaches and Strategies. Report for the Distance Learning Working Group. Greenwich Connect, University of Greenwich. 
Barber M, Donnelly K \& Rizvi S (2013) An avalanche is coming: Higher education and the revolution ahead. Institute for Public Policy Research, Essay, March 2013.

http://www.ippr.org/assets/media/images/media/files/publication/2013/04/avalanche-iscoming_Mar2013_10432.pdf Cited 31 Jul 2014

Barroso FG, Haro C de, Sánchez-Muros MJ, Venegas E, Martínez-Sánchez A \& Pérez-Bañón C. (2014) The potential of various insect species for use as food for fish. Aquaculture 422423: 193-201. doi:10.1016/j.aquaculture.2013.12.024

Beveridge MCM, Thilsted SH, Phillips MJ, Metian M, Troell M \& Hall SJ (2013) Meeting the food and nutrition needs of the poor: the role of fish and the opportunities and challenges emerging from the rise of aquaculture. Journal of Fish Biology 83: 1067-1084.

DOI:10.1111/jfb.12187

Bonk CJ \& Graham CR (2012) The handbook of blended learning: Global perspectives, local designs. John Wiley \& Sons, San Francisco, USA. 624pp.

Bush SR, Belton B, Hall D, Vandergeest P, Murray FJ, Ponte S, Oosterveer, P, Islam MS, Mol APJ, Hatanaka M, Kruijssen F, Ha TTT, Little DC \& Kusumawati R (2013) Certify sustainable aquaculture? Science 341 (6150): 1067-1068. DOI: 10.1126/science.1237314

Briggs S (2013) Out with the degree, in with the badge: How badges motivate learning and 7 tips to use it right. InformED Blog Article: http://www.opencolleges.edu.au/informed/features/badges-in-education/ Cited 8 Aug 2014

Cao L, Diana JS \& Keoleian GA (2013) Role of life cycle assessment in sustainable aquaculture. Reviews in Aquaculture 5: 61-71. DOI: 10.1111/j.1753-5131.2012.01080.x

CEDEFOP 2014, Monitoring ECVET implementation strategies in Europe in 2013, Luxembourg 176p. http://www.cedefop.europa.eu/files/6122_en.pdf 
Čičkováa H, Newton GL, Lacy RC \& Kozáneka M (2015) The use of fly larvae for organic waste treatment. Waste Treatment 35: 68-80 doi:10.1016/j.wasman.2014.09.026.

Deem R, Mok KH, Lucas L (2008) Transforming higher education in whose image? Exploring the concept of the 'world-class' university in Europe and Asia. Higher Education Policy 21: 83-97. DOI:10.1057/palgrave.hep.8300179

Docampo D (2007) International comparisons in higher education funding. Higher Education in Europe 32(4): 369-386. DOI: 10.1080/03797720802066252.

Domik G \& Fischer G (2011) Transdisciplinary collaboration and lifelong learning: Fostering and supporting new learning opportunities. IN: Rainbow of computer science, Lecture Notes in Computer Science Volume 6570, pp 129-143.

http://link.springer.com/chapter/10.1007/978-3-642-19391-0_10 Cited 10 Aug 2014

Downes S (2012) Connectivism and connective knowledge: Essays on meaning and learning networks. National Research Council, Canada. Available via http://www.downes.ca/files/books/Connective_Knowledge-19May2012.pdf Cited 8 Aug 2014

Drago-Severson E, Helsing D, Kegan R, Popp N, Broderick M, Portnow K (2001) The power of cohort and of collaborative groups. Focus on Basics. 5 (B): 15-22. http://www.ncsall.net/fileadmin/resources/fob/2001/fob_5b.pdf Cited 7 Aug 2014

Eleftheriou M \& Seixas S. (2014) Positioning lifelong learning in aquaculture: challenges and opportunities. In Press, Aquaculture International. DOI 10.1007/s10499-014-9826-y

Ernst \& Young (2012) University of the Future. Ernst \& Young, Australia. Available via http://www.ey.com/Publication/vwLUAssets/University_of_the_future/\$FILE/University_of the future_2012.pdf Cited 12 Aug 2014 
European Commission (2002) Communication from the Commission to the Council and The European Parliament on a Strategy for the Sustainable Development of European Aquaculture, $\operatorname{COM}(2002) 511$ final, European Commission, Brussels. Available via http://www.fp7.org.tr/tubitak_content_files//268/dokumanlar/Aquaculture_Strategy.pdf Cited $31 \mathrm{Jul} 2014$

European Commision (2009) Communication from the Commission to the European Parliament and the Council - Building a sustainable future for aquaculture. A new impetus for the Strategy for the Sustainable Development of European Aquaculture, COM(2009) 162 final, European Commission, Brussels. Available via http://eur-lex.europa.eu/legalcontent/EN/ALL/?uri=CELEX:52009DC0162 Cited 31 July 2014

European Commission (2009a) Council conclusions of 12 May 2009 on a strategic framework for European cooperation in education and training ('ET 2020'). Notices from the European Union Institutions and Bodies. Official Journal of the European Union (2009/C 119/02). Available via http://eur-lex.europa.eu/legalcontent/EN/TXT/PDF/?uri=CELEX:52009XG0528(01)\&from=EN Cited 7 Aug 2014 European Commission (2011) Supporting growth and jobs - an agenda for the modernisation of Europe's higher education systems. Communication from the Commission to the European Parliament, The Council, The European Social and Economic Committee and The Committee of the Regions. COM(2011) 0567 final. Available via http://eur-lex.europa.eu/legalcontent/EN/ALL/?uri=CELEX:52011DC0567 Cited 5 Aug 2014

European Commission (2012) Rethinking education: Investing in skills for better socioeconomic outcomes. Communication from the Commission to the European Parliament, The Council, The European Social and Economic Committee and The Committee of the Regions. 
$\operatorname{COM}(2012) 669$ final. Available via http://eur-lex.europa.eu/legalcontent/EN/TXT/?qid=1389778594543\&uri=CELEX:52012DC0669

European Commission (2013) Communication from the Commission to the European Parliament, The Council, The European Economic and Social Committee and the Committee of the Regions - Strategic Guidelines for the sustainable development of EU aquaculture. $\operatorname{COM}(2013) 229$ final, Brussels. Available via http://ec.europa.eu/fisheries/cfp/aquaculture/official_documents/com_2013_229_en.pdf European Commission (2013a) Opening up education: Innovative teaching and learning through new technologies and open educational resources. Communication from the Commission to the European Parliament, The Council, The European Social and Economic Committee and The Committee of the Regions. COM(2013) 654 Final. \{SWD(2013) 341 final \}. Available via http://eur-lex.europa.eu/legalcontent/EN/TXT/PDF/?uri=CELEX:52013DC0654\&from=EN Cited 13 Aug 2014 European Commission (2014) Towards a circular economy: A zero waste programme for Europe. Communication from the Commission to the European Parliament, The Council, The European Social and Economic Committee and The Committee of the Regions. COM(2014) 0398 final. Available via http://eur-lex.europa.eu/legalcontent/EN/TXT/?uri=CELEX:52014DC0398 Cited 7 Aug 2014

European Commission (2014a) Cohesion Policy 2014-2020. Fact Sheet. EC National/Regional Innovation Strategies for Smart Specialisation (RIS3). Available via http://ec.europa.eu/regional_policy/sources/docgener/informat/2014/smart_specialisation_en. pdf 
European Higher Education Area Ministerial Conference (2012) Making the most of our potential: Consolidating the European Higher Education Area. "The Bucharest Communiqué". Available via http://www.minedu.fi/OPM/Koulutus/artikkelit/bologna/liitteet/Bucharest_Communique.pdf Cited 13 Aug 2014

Failler P (2007) Future prospects for fish and fishery products. 4. Fish consumption in the European Union in 2015 and 2030. Part 1. European overview. FAO Fisheries Circular 972/4 Part 1. Rome, FAO. 204p. Available via ftp://ftp.fao.org/docrep/fao/010/ah947e/ah947e.pdf Cited 31 Jul 2014

FAO (2010) Aquaculture Development, (4) Ecosystem approach to aquaculture. FAO Technical Guidelines for Responsible Fisheries 5, Suppl. 4. United Nations Food and Agriculture Organisation, Rome. Available via http://www.fao.org/docrep/013/i1750e/i1750e.pdf Cited 12 Jul 2014

FAO (2011) World aquaculture 2010. FAO Fisheries and Aquaculture Department. Technical Paper 500 (1). Rome, FAO. 105 pp. Available via http://www.fao.org/docrep/014/ba0132e/ba0132e00.htm FAO (2014) The state of world fisheries and aquaculture 2014. United Nations Food and Agriculture Organisation, Rome. Available via http://www.fao.org/3/a-i3720e.pdf FAO (2014a) FishStat aquaculture production data to 2012. United Nations Food and Agriculture Organisation, Rome. Available via http://www.fao.org/fishery/statistics/software/fishstatj/en Franceschi K, Lee RM, Zanakis SH, Hinds D (2009) Engaging group e-learning in virtual worlds. Journal of Management Information Systems 26 (1): 73-100. 
http://mesharpe.metapress.com/openurl.asp?genre=article\&id=doi:10.2753/MIS0742$\underline{1222260104}$

Guerrero RD \& Guerrero LA (2014) Production of viermicompost and earthworm biomass (Eudrilus eugeniae) for organic Nile tilapia (Oreochromis niloticus) culture in freshwater ponds. Journal of Fisheries and Aquaculture 5(1): 154-157. Available via http://www.bioinfopublication.org/files/articles/5_1_1_JFA.pdf

Higher Education Strategy Group (2011) National Strategy for Higher Education to 2030. Department of Education and Skills, Government of Ireland. Available via http://www.hea.ie/sites/default/files/national_strategy_for_higher_education_2030.pdf

Hishamunda N, Bueno P, Menezes A M, Ridler N, Wattage P, Martone E (2014) FAO Fisheries and Aquaculture e-Bulletin. Improving governance in aquaculture employment: a global assessment. FAO Fisheries and Aquaculture Technical Paper 575. Rome, FAO. 48 pp. Available via http://issuu.com/alieia.info/docs/improving_governance_of_aquaculture

Irisarri J, Fernández-Reiriza M J, Robinsonb S M C, Cranfordc P J, Labartaa U (2013) Absorption efficiency of mussels Mytilus edulis and Mytilus galloprovincialis cultured under Integrated Multi-Trophic Aquaculture conditions in the Bay of Fundy (Canada) and Ría AresBetanzos (Spain), Aquaculture 388-391: 182-192. DOI: 10.1016/j.aquaculture.2013.01.034

Ivanova M (2009) From personal learning environment building to professional learning network forming. $5^{\text {th }}$ International Scientific Conference on eLearning and software for education. Bucharest, April 09-10, 2009. Available via https://adlunap.ro/else2009/papers/1001.1.Ivanova.pdf Cited 12 Aug 2014 Jacoby J (2014) The disruptive potential of the Massive Open Online Course: A literature review. Journal of Open, Flexible and Distance Learning, 18(1); 73-85. Available from 
http://journals.akoaotearoa.ac.nz/index.php/JOFDL/article/viewFile/214/168 Cited 23 Aug 2014

LANTRA (2010) Aquaculture National Occupational Standards. Lantra, UK. Available via http://www.lantra.co.uk/getattachment/522200b4-28da-4f42-9f21-

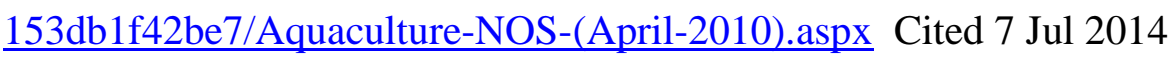

Lokhoff J, Wegewijs B, Durkin K, Wagenaar R, González J, Isaacs A K, Donà dalle Rose, LF, Gobbi M (Eds) (2010) A Tuning guide to formulating degree programme profiles including programme competences and programme learning outcomes. Universidad de Deusto, Bilbao, Spain. Available via http://coreproject.eu/documents/Tuning\%20G\%20Formulating\%20Degree\%20PR4.pdf Love DC, Fry JP, Li X, Hill ES, Genello L, Semmens K \& Thompson RE. (2015) Commercial aquaponics production and profitability: Findings from an international survey. Aquaculture, 435: 67-74. doi:10.1016/j.aquaculture.2014.09.023

Martins CIM, Eding EH, Verdegema MCJ, Heinsbroek LTN, Schneider O, Blancheton JP, d'Orbcasteld ER \& Verreth JAJ. (2010) New developments in recirculating aquaculture systems in Europe: A perspective on environmental sustainability. Aquacultural Engineering 43 (3): 83-89. DOI:10.1016/j.aquaeng.2010.09.002.

Nixon J (2004) Education for the good society: the integrity of academic practice. London Review of Education (Special Issue: Renewing Education for Civic Society) 2-3: 245-252. http://www.tlrp.org/themes/seminar/gewirtz/papers/seminar3/paper\%20-\%20nixon.doc Cited 15 Aug 2014 
Samuel-Fitwi B, Wuertz S, Schroeder J, Schulz C (2012) Sustainability assessment tools to support aquaculture development. Journal of Cleaner Production 32: 183-192. DOI: 10.1016/j.jclepro.2012.03.037

Senge P M (2006) The fifth discipline: The art \& practice of the Learning Organisation. Second Edition, Random House Business Books, London.

Seixas S, Bostock J, Eleftheriou M (2012) Promoting sustainable aquaculture: Building the capacity of local institutions and online teaching (elearning), Management of Environmental Quality: An International Journal 23(4): $434-450$.

http://dx.doi.org/10.1108/14777831211232245

Shelton C (2014) Climate change adaptation in fisheries and aquaculture: Compilation of initial examples. FAO Fisheries and Aquaculture Circular No. 1088, FIPI/C1088 (En). FAO, Rome. Available via http://www.fao.org/docrep/019/i3569e/i3569e.pdf

Soriano FH, Mulatero F (2010) Knowledge policy in the EU: From the Lisbon Strategy to Europe 2020. J Knowl. Econ (4): 289-302. DOI: 10.1007/s13132-010-0020-9

STECF (2013) JRC Scientific and Policy Report: The Economic Performance of the EU Aquaculture Sector (STECF 13-29). Scientific, Technical and Economic Committee for Fisheries (STECF). Guillen J, Motova A (Eds) European Commission, Joint Research Centre, Ispara, Italy. Available via http://stecf.jrc.ec.europa.eu/documents/43805/622206/2013-12_STECF+13-29++Aquaculture+economics_JRCxxx.pdf Cited 3 Jul 2014

Sursock A, Smidt H (2010) Trends 2010: A decade of change in European Higher Education. European University Association Publication. Available via 
http://www.eua.be/typo3conf/ext/bzb_securelink/pushFile.php?cuid=399\&file=fileadmin/use r_upload/files/Publications/Trends_2010.pdf Cited 21 Jul 2014

Taneja S, Goel A (2014) MOOC providers and their strategies. IJCSMC, 3(5): 222-228. Available from http://ijcsmc.com/docs/papers/May2014/V3I5201462.pdf Cited 23 Aug 2014

TLRP (2008) Putting Knowledge to Work: Integrating work-based and subject based knowledge in intermediate-level qualifications and workforce upskilling. Teaching and Learning Research Briefing 60, Teaching and Learning Research Programme. Available via http://www.tlrp.org/pub/documents/EvansRB60.pdf Cited 14 Jul 2014

Troell M, Joyce A, Chopin T, Neori A, Buschmann AH, Fang JG (2009) Ecological engineering in aquaculture- Potential for integrated multi-trophic aquaculture (IMTA) in marine offshore systems. Aquaculture 297: 1-9. Doi: 10.1016/j.aquaculture.2009.09.010 Valderrama D, Hishamunda N, Zhou X (2010) Estimating employment in world aquaculture. FAO Aquaculture Newsletter 45: 24-25. http://www.fao.org/docrep/012/al363e/al363e12.pdf Cited Jul 201

Vidovich L, Currie J (2014) Aspiring to 'World Class' universities in Australia: A global trend with intended and unintended consequences. Chapter 22 In: The Forefront of International Higher Education. Higher Education Dynamics 42: 295-307. http://link.springer.com/chapter/10.1007/978-94-007-7085-0_22

Waite R, Beveridge M, Brummett R, Castine S, Chaiyawannakarn N, Kaushik S, Mungkung R, Nawapakpilai S, Phillips M (2014) Improving productivity and environmental performance of aquaculture. Installment 5 of Creating a sustainable food future. World Resources Institute Working Paper. Available via http://www.wri.org/publication/improvingaquaculture Cited 27 Jul 2014 
Wang WKS (1975) The unbundling of higher education. Duke Law Journal 53: 53-90. http://scholarship.law.duke.edu/cgi/viewcontent.cgi?article $=2514 \&$ context $=\mathrm{dlj}$

Wenger E (2012) Communities of practice: a brief introduction. Available via http://wengertrayner.com/wp-content/uploads/2012/01/06-Brief-introduction-to-communities-ofpractice.pdf Cited 6 Aug 2014

World Bank (2013) Fish to 2030: Prospects for Fisheries and Aquaculture. Agriculture \& Environmental Services Discussion Paper 03. World Bank Report No. 83177-GLB. Available via http://www.fao.org/docrep/019/i3640e/i3640e.pdf Cited 22 Jul 2014

World Economic Forum (2014) Education and skills 2.0: New targets and innovative approaches. World Economic Forum, Geneva, Switzerland. Available via http://www3.weforum.org/docs/GAC/2014/WEF_GAC_EducationSkills_TargetsInnovativeA pproaches_Book_2014.pdf cited 2 Jul 2014 


\section{ENDNOTES}

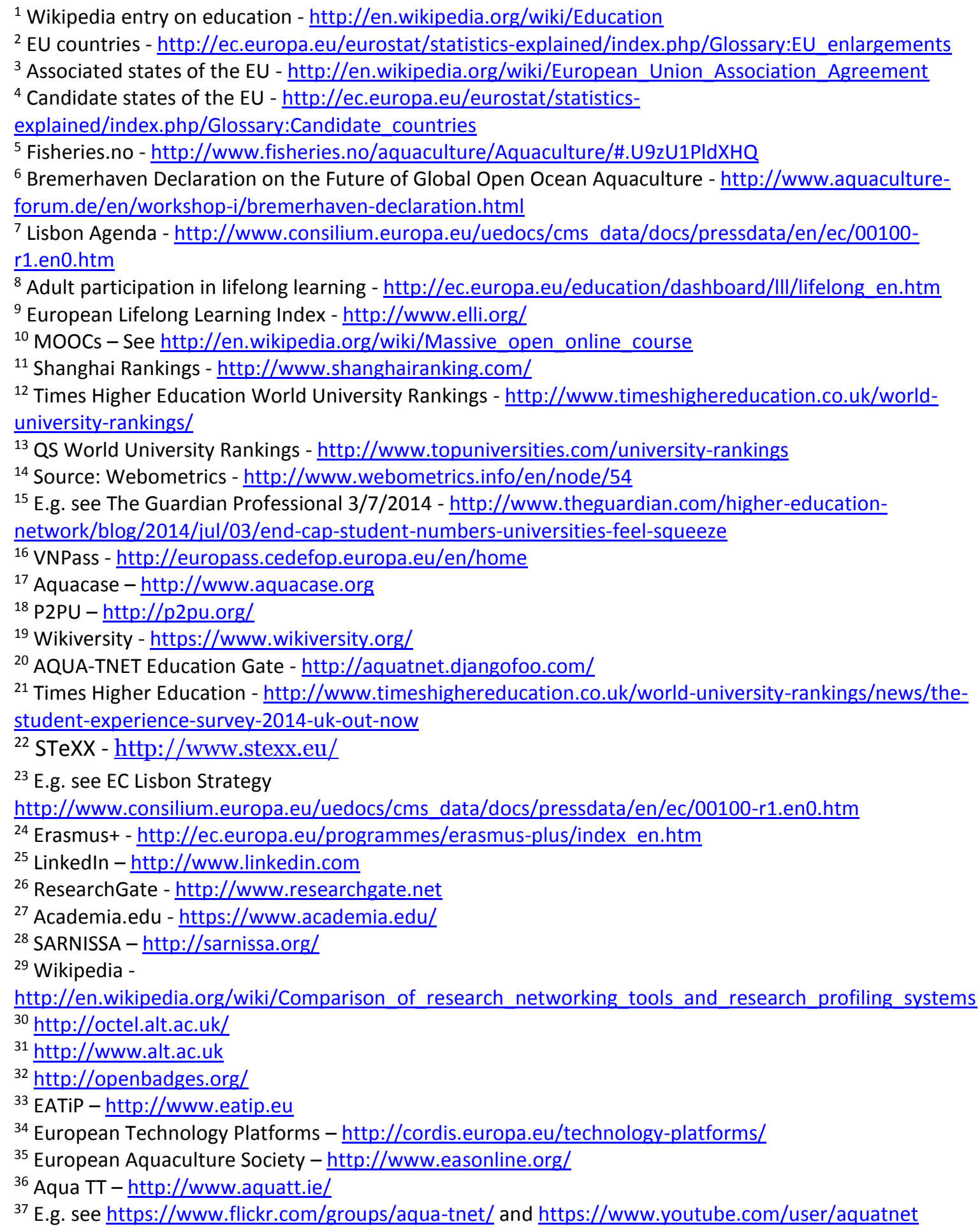

